\title{
PEMANASAN GLOBAL, EKSPLOITASI SUMBERDAYA PERIKANAN, DAN PENCEMARAN PESISIR SEBAGAI PENYEBAB UTAMA PERUBAHAN EKOLOGI LAUT DI INDONESIA
}

\author{
Oleh \\ Hadiyanto $^{1)}$
}

\begin{abstract}
GLOBAL WARMING, OVERFISHING, AND COASTAL POLLUTION AS MAJOR CAUSES OF MARINE ECOLOGICAL CHANGES IN INDONESIA. Changes in marine ecology are normal, because the earth is dynamic, and are getting worse and faster since human are involved in their processes, indicating the Anthropocene Era begins. Consequently, three parameters to measure the quality of the earth for living, i.e. climate changes, rate of biodiversity loss, and nitrogen cycles, have been over the maximum thresholds. In general, changes in marine ecology are caused by phenomena that are occuring in global scale (e.g. increasing of $\mathrm{CO}_{2}$ emission, global warming, and ocean acidification), regional scale (e.g. overfishing, and changes in oceagraphical processes, rain and storm), and local scale (e.g. eutrophication, sedimentation, pollution, biological invasions, herbivory, and diseases). Result of reviews shows that major causes of changes in marine ecology in Indonesia may be global warming, overfishing, and coastal pollution. As a result, species richness, abundance, distribution, and community structure of marine ecosystems in Indonesia change significantly.
\end{abstract}

\section{PENDAHULUAN}

Perubahan proses-proses ekologi adalah hal normal dan pasti terjadi, karena bumi yang kita tempati ini bersifat dinamis. Kepunahan dan kemunculan mahluk hidup telah terjadi beberapa kali dalam kurun waktu proses geologi, dan beberapa diantaranya mampu bertahan selama perubahan tersebut terjadi. Perubahan ekologi akhir-akhir ini semakin tidak teratur dan semakin cepat, sejak manusia terlibat di dalam proses-prosesnya yang menandai dimulainya era baru, yang disebut Anthropocene (Lewis \& Maslin,
2015). Namun demikian, masih terdapat perdebatan di antara beberapa pakar mengenai kapan Anthropocene dimulai.

Beberapa pakar sepakat bahwa Anthropocene dimulai antara tahun 1610 atau 1960. Anthropocene dimulai tahun 1610 yang didukung dengan tiga bukti, yaitu: kedatangan orang-orang Eropa ke Amerika, yang menyebabkan 50 juta kematian dan 65 juta ha hutan dikonversi menjadi lahan pertanian; gas karbondioksida berada pada titik terendah; dan dimulainya migrasi lintas samudera yang berimplikasi pada serangan biota asing.

1) Pusat Penelitian Oseanografi LIPI 
Alternatifnya, Anthropocene berawal pada tahun 1960 yang didasarkan pada penemuan bahan-bahan sintetis, seperti plastik dan bahan berbahaya dan beracun lainnya, tes nuklir, dan pertambahan penduduk yang sangat cepat (Lewis \& Maslin, 2015).

Tabel 1. Batasan kelayakan bumi sebagai tempat hidup (Rockström, 2009)

\begin{tabular}{|c|c|c|c|c|}
\hline \multicolumn{5}{|c|}{ PLANETARY BOUNDARIES } \\
\hline Earth-system process & Parameters & $\begin{array}{l}\text { Proposed } \\
\text { boundary }\end{array}$ & $\begin{array}{l}\text { Current } \\
\text { status }\end{array}$ & $\begin{array}{l}\text { Pre-industrial } \\
\text { value }\end{array}$ \\
\hline \multirow[t]{2}{*}{ Climate change } & $\begin{array}{l}\text { (i) Atmospheric carbon dioxide } \\
\text { concentration (parts per million } \\
\text { by volume) }\end{array}$ & 350 & 387 & 280 \\
\hline & $\begin{array}{l}\text { (ii) Change in radiative forcing } \\
\text { (watts per metre squared) }\end{array}$ & 1 & 1.5 & 0 \\
\hline Rate of biodiversity loss & $\begin{array}{l}\text { Extinction rate (number of species } \\
\text { per million species per year) }\end{array}$ & 10 & $>100$ & $0.1-1$ \\
\hline $\begin{array}{l}\text { Nitrogen cycle (part } \\
\text { of a boundary with the } \\
\text { phosphorus cycle) }\end{array}$ & $\begin{array}{l}\text { Amount of } \mathrm{N}_{2} \text { removed from } \\
\text { the atmosphere for human use } \\
\text { (millions of tonnes per year) }\end{array}$ & 35 & 121 & 0 \\
\hline $\begin{array}{l}\text { Phosphorus cycle (part } \\
\text { of a boundary with the } \\
\text { nitrogen cycle) }\end{array}$ & $\begin{array}{l}\text { Quantity of P flowing into the } \\
\text { oceans (millions of tonnes per year) }\end{array}$ & 11 & $8.5-9.5$ & $\sim 1$ \\
\hline $\begin{array}{l}\text { Stratospheric ozone } \\
\text { depletion }\end{array}$ & $\begin{array}{l}\text { Concentration of ozone (Dobson } \\
\text { unit) }\end{array}$ & 276 & 283 & 290 \\
\hline Ocean acidification & $\begin{array}{l}\text { Global mean saturation state of } \\
\text { aragonite in surface sea water }\end{array}$ & 2.75 & 2.90 & 3.44 \\
\hline Global freshwater use & $\begin{array}{l}\text { Consumption of freshwater } \\
\text { by humans ( } \mathrm{km}^{3} \text { per year) }\end{array}$ & 4,000 & 2,600 & 415 \\
\hline Change in land use & $\begin{array}{l}\text { Percentage of global land cover } \\
\text { converted to cropland }\end{array}$ & 15 & 11.7 & Low \\
\hline $\begin{array}{l}\text { Atmospheric aerosol } \\
\text { loading }\end{array}$ & $\begin{array}{l}\text { Overall particulate concentration in } \\
\text { the atmosphere, on a regional basis }\end{array}$ & \multicolumn{3}{|c|}{ To be determined } \\
\hline Chemical pollution & $\begin{array}{l}\text { For example, amount emitted to, } \\
\text { or concentration of persistent } \\
\text { organic pollutants, plastics, } \\
\text { endocrine disrupters, heavy metals } \\
\text { and nuclear waste in, the global } \\
\text { environment, or the effects on } \\
\text { ecosystem and functioning of Earth } \\
\text { system thereof }\end{array}$ & \multicolumn{3}{|c|}{ To be determined } \\
\hline
\end{tabular}

Terlepas kapan era Anthropocene dimulai, saat ini keadaan bumi sudah mulai memburuk. Hal ini dapat dilihat dari status terkini sembilan parameter untuk menilai kelayakan bumi sebagai tempat hidup, yaitu: perubahan iklim, laju kepunahan keanekaragaman hayati, siklus nitrogen dan fosfor, pengasaman 
air laut, pencemaran kimiawi, penurunan ozon di lapisan stratosfer, penggunaan air tawar, perubahan tata guna lahan, dan konsentrasi gas di atmosfer. Lima parameter pertama, sangat erat kaitannya dengan proses-proses ekologi laut. Tiga di antara sembilan parameter tersebut yaitu perubahan iklim, laju kepunahan keanekaragaman hayati, dan siklus nitrogen diyakini telah melebihi batas atas, sehingga sudah tidak layak untuk keberlangsungan mahluk hidup (Tabel 1) (Rockström, 2009).

Upaya mencari penyebab perubahan ekologi laut terus dilakukan, guna merumuskan langkah-langkah yang dapat menekan dampak Anthropocene. Perubahan ekologi laut secara umum disebabkan oleh proses-proses yang terjadi di tingkat global, regional, dan lokal. Di tingkat global, penyebab perubahan ekologi laut antara lain: peningkatan emisi gas karbondioksida, peningkatan suhu air laut, dan penurunan $\mathrm{pH}$ air laut. Di tingkat regional, perubahan ekologi laut disebabkan oleh eksploitasi sumberdaya perikanan, perubahan proses-proses oseanografi, dan perubahan pola hujan dan badai. Sementara itu, eutrofikasi, sedimentasi, pencemaran, dan serangan biologi dari spesies asing, herbivora, dan penyakit adalah beberapa penyebab perubahan ekologi di tingkat lokal. Dengan demikian, beban perubahan ekologi laut akan terakumulasi di tingkat lokal (Wernberg et al., 2011).
Penyebab perubahan ekologi laut di setiap tempat berbeda-beda, bahkan pada tingkat negara. Sebagai contoh, perubahan ekologi laut di Australia dipicu oleh peningkatan suhu air laut, eksploitasi sumberdaya perikanan, dan serangan biota asing (Wernberg et al., 2011). Lalu, bagaimana penyebab dan dampak perubahan ekologi laut di Indonesia? Indonesia dan Australia berbeda dalam beberapa hal karakteristik ekosistem laut dan pertumbuhan kawasan pesisir, sehingga penyebab perubahan ekologi laut di Indonesia mungkin berbeda dengan Australia. Artikel ini membahas penyebab utama dan dampak perubahan ekologi laut di Indonesia secara singkat.

\section{PEMANASAN GLOBAL SEBAGAI FENOMENA GLOBAL PENYEBAB PERUBAHAN EKOLOGI LAUT DI INDONESIA}

Penyebab perubahan ekologi laut pada skala global adalah peningkatan emisi gas karbondioksida, peningkatan suhu air laut, dan penurunan $\mathrm{pH}$ air laut (Wernberg et al., 2011). Ketiga faktor tersebut saling terkait satu sama lain. Peningkatan emisi gas karbondioksida yang dihasilkan baik secara alami ataupun hasil kegiatan industri merupakan penyebab peningkatan suhu air laut dan penurunan $\mathrm{pH}$ air laut. Data berkala emisi gas karbondioksida, suhu, dan $\mathrm{pH}$ air laut di Indonesia sangat terbatas, sehingga cukup sulit untuk menentukan faktor apa yang menjadi penyebab utama perubahan ekologi ekosistem laut di Indonesia. 


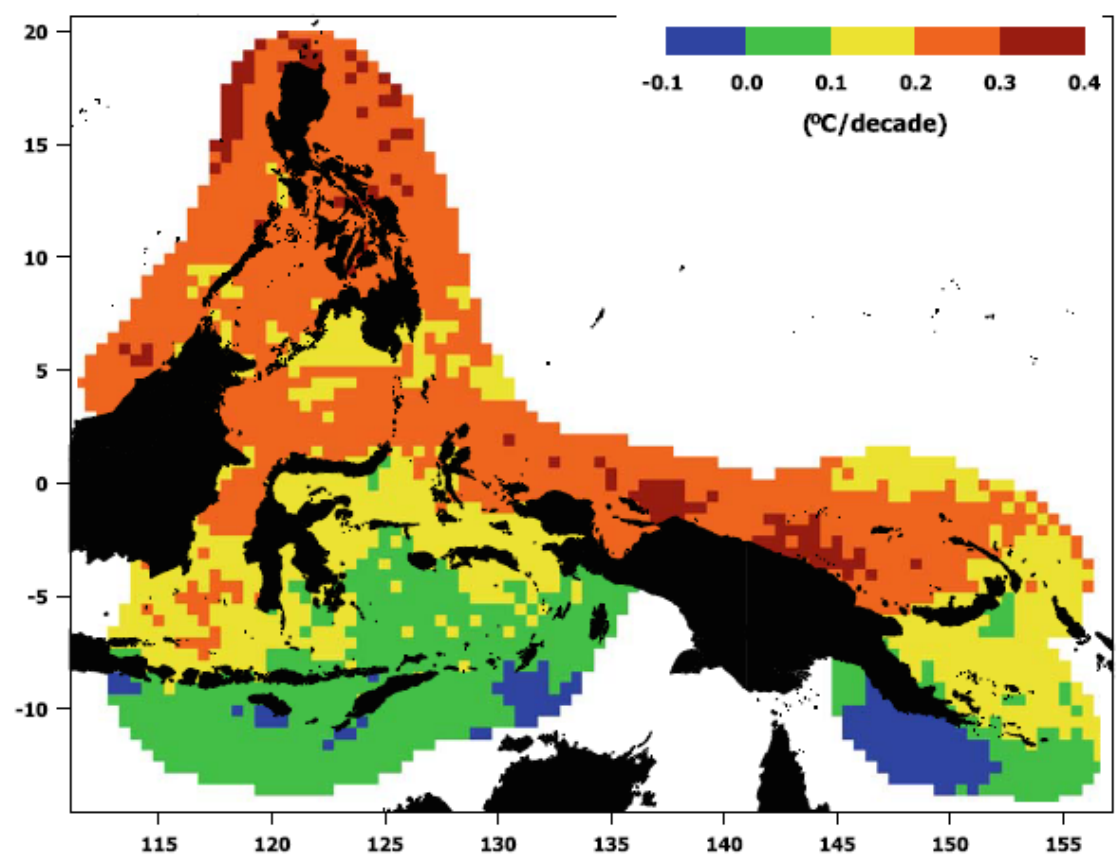

Gambar 1. Pola suhu permukaan air laut pada kurun waktu 1985 hingga 2006 (Peñaflor et al., 2009).

Di antara ketiga faktor tersebut, peningkatan suhu air laut di Indonesia nampak relatif lebih banyak dipelajari dibandingkan dua faktor lainnya. Hasil pemodelan pada kurun waktu 1985 hingga 2006, menunjukkan bahwa suhu air laut di kawasan segitiga ekosistem karang
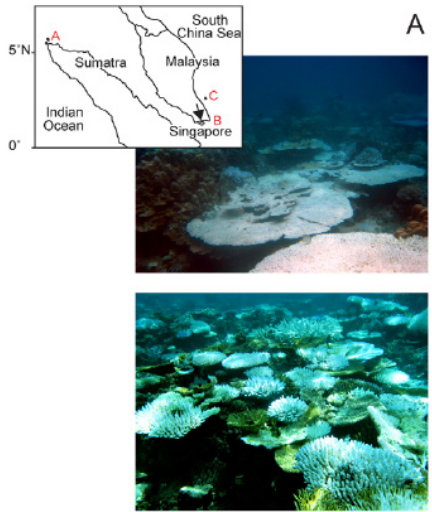

A
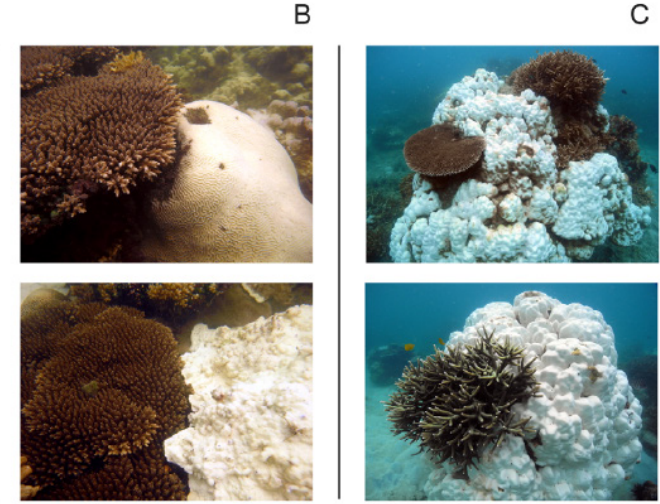

Gambar 2. Pemutihan terumbu karang di Pulau Weh, Sumatera Utara (A), Singapura (B), dan Pulau Tioman, Malaysia (C) (Guest et al., 2012). 
Peningkatan suhu air laut sangat mempengaruhi metabolisme semua biota laut, sehingga dampaknya diduga lebih buruk dibandingkan dengan penurunan $\mathrm{pH}$ air laut. Sebagai contoh, terumbu karang mampu beradaptasi terhadap penurunan $\mathrm{pH}$ air laut, karena dapat mengatur $\mathrm{pH}$ dalam tubuh 1.5 kali lebih tinggi daripada $\mathrm{pH}$ lingkungan, dengan energi yang cukup rendah yaitu kurang dari $1 \%$ dari energi untuk fotosintesis (McCulloch et al., 2012). Akan tetapi, terumbu karang tidak tahan terhadap peningkatan suhu air laut yang menyebabkan pemutihan (coral bleaching). Pemutihan terumbu karang terjadi karena suhu air laut terlalu tinggi bagi zooxanthellae yang bersimbiosis dengan karang, sehingga biota tersebut melepaskan diri dari simbiosis tersebut. Akibatnya, terumbu karang kehilangan warna atau memutih dan tidak dapat melakukan fotosintesis. Pemutihan terumbu karang pada skala besar pernah terjadi di Pulau Weh, Sumatera Utara, pada bulan Mei-Juni 2010, sebagai akibat gelombang panas yang melanda Asia Tenggara. Gelombang panas meningkatkan suhu air laut $1.5-2^{\circ} \mathrm{C}$ lebih tinggi dari pada rata-rata suhu air laut untuk jangka panjang. Sebanyak $87 \%$ Pocillopora dan 97\% Acropora telah dilaporkan mengalami pemutihan dan mati selama gelombang panas tersebut berlangsung (Gambar 2) (Guest et al., 2012).
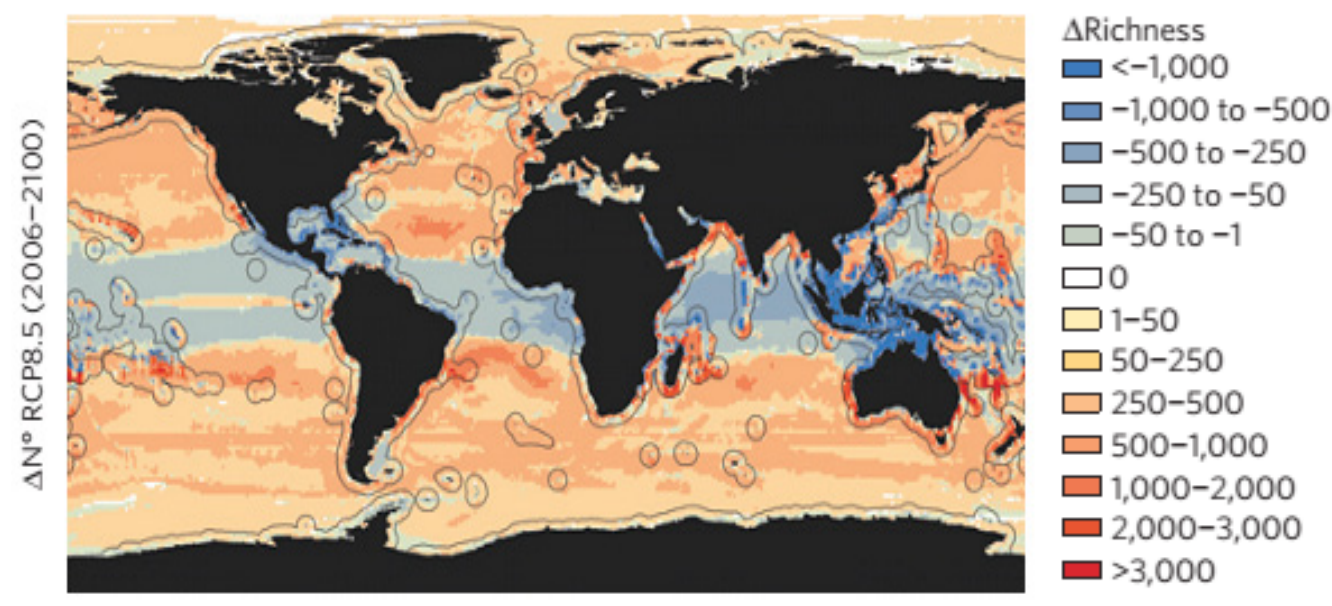

Gambar 3. Penyebaran biota laut di bawah skenario iklim masa depan (García Molinos et al., 2016).

Peningkatan suhu air laut juga mempengaruhi penyebaran biota laut di Indonesia. Kurang lebih 1000 spesies biota laut di Indonesia akan bermigrasi ke selatan (Australia) pada 100 tahun ke depan untuk menemukan suhu air laut yang sesuai (Gambar 3) (García-Molinos et al., 2016). Migrasi tersebut tidak melibatkan seluruh komponen ekosistem, melainkan hanya beberapa komponen yaitu biota laut yang rentan terhadap pemanasan air laut. Biota yang memiliki toleransi luas terhadap suhu air laut mungkin akan tetap tinggal di tempat asal. Akibatnya, keseimbangan ekosistem terutama hubungan antara mangsa dan pemangsa di tempat asal dan 
tempat tujuan menjadi tidak seimbang (Sydeman et al., 2015). Oleh karena itu, peningkatan suhu air laut sering diikuti dengan kejadian serangan biota asing sebagai hasil dari migrasi tersebut.

\section{EKSPLOITASI SUMBERDAYA PERIKANAN SEBAGAI FENOMENA REGIONAL PENYEBAB PERUBAHAN EKOLOGI LAUT DI INDONESIA}

Di tingkat regional, perubahan ekologi laut disebabkan oleh aktivitas fisika laut, seperti perubahan proses oseanografi, pola hujan dan badai, dan aktivitas manusia di laut terutama eksploitasi sumberdaya perikanan (Wernberg et al., 2011). Perubahan proses oseanografi di Indonesia ditentukan oleh El Nino-Southern Oscillation (ENSO), yang sering terjadi sepanjang bulan Juni hingga September (Steinke et al., 2014). El Nino pada tahun 19821983 telah menurunkan keanekaragaman dan merubah komposisi terumbu karang di Kepulauan Seribu, Jakarta (Warwick et al., 1990). Pemulihan terumbu karang setelah terjadi El Nino membutuhkan waktu yang cukup lama. Sebagai contoh, terumbu karang di Pulau Kokos, Samudera Pasifik, baru pulih 23-58\% setelah 20 tahun (Guzman \& Cortés, 2007).

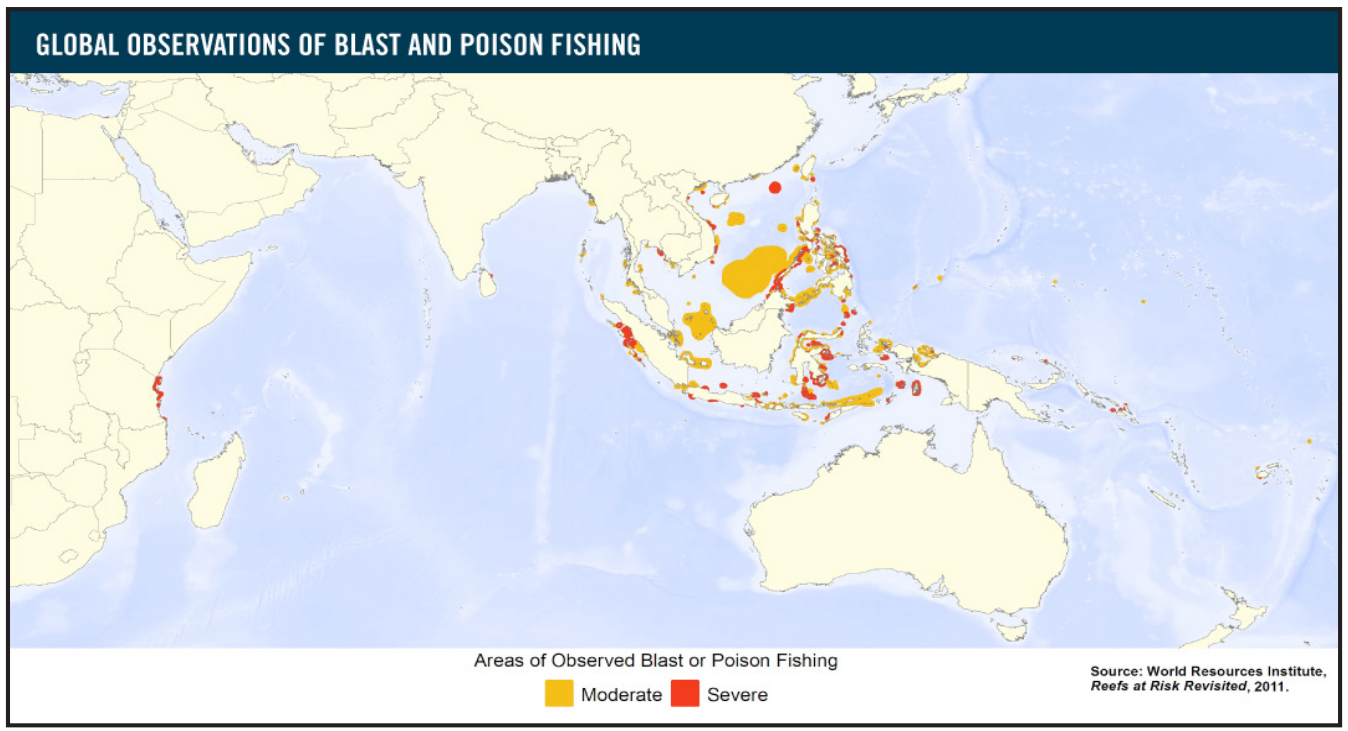

Gambar 4. Sebaran penggunaan bom atau racun untuk menangkap ikan (Burke et al., 2011).

Akan tetapi, dampak perubahan pola oseanografi terhadap ekosistem laut di Indonesia mungkin tidak seburuk dampak eksploitasi sumberdaya perikanan. Frekuensi eksploitasi sumberdaya perikanan lebih sering daripada kejadian El Nino. Contoh nyata eksploitasi sumberdaya perikanan di Indonesia adalah maraknya penggunan bom dan racun untuk menangkap ikan, seperti yang terjadi di kawasan timur Indonesia. Frekuensi penggunaan bom dan racun di perairan Indonesia timur berkisar 
antara sedang (moderate) yaitu satu kali per bulan, dan tinggi (severe) yaitu satu kali per minggu (Gambar 4) (Burke et al., 2011). Dampak penggunaan bom untuk menangkap ikan terlihat nyata terhadap terumbu karang. Sebagai contoh, lebih dari $50 \%$ tutupan karang hancur akibat penggunaan bom di perairan Sulawesi Selatan (Edinger et al., 1998).
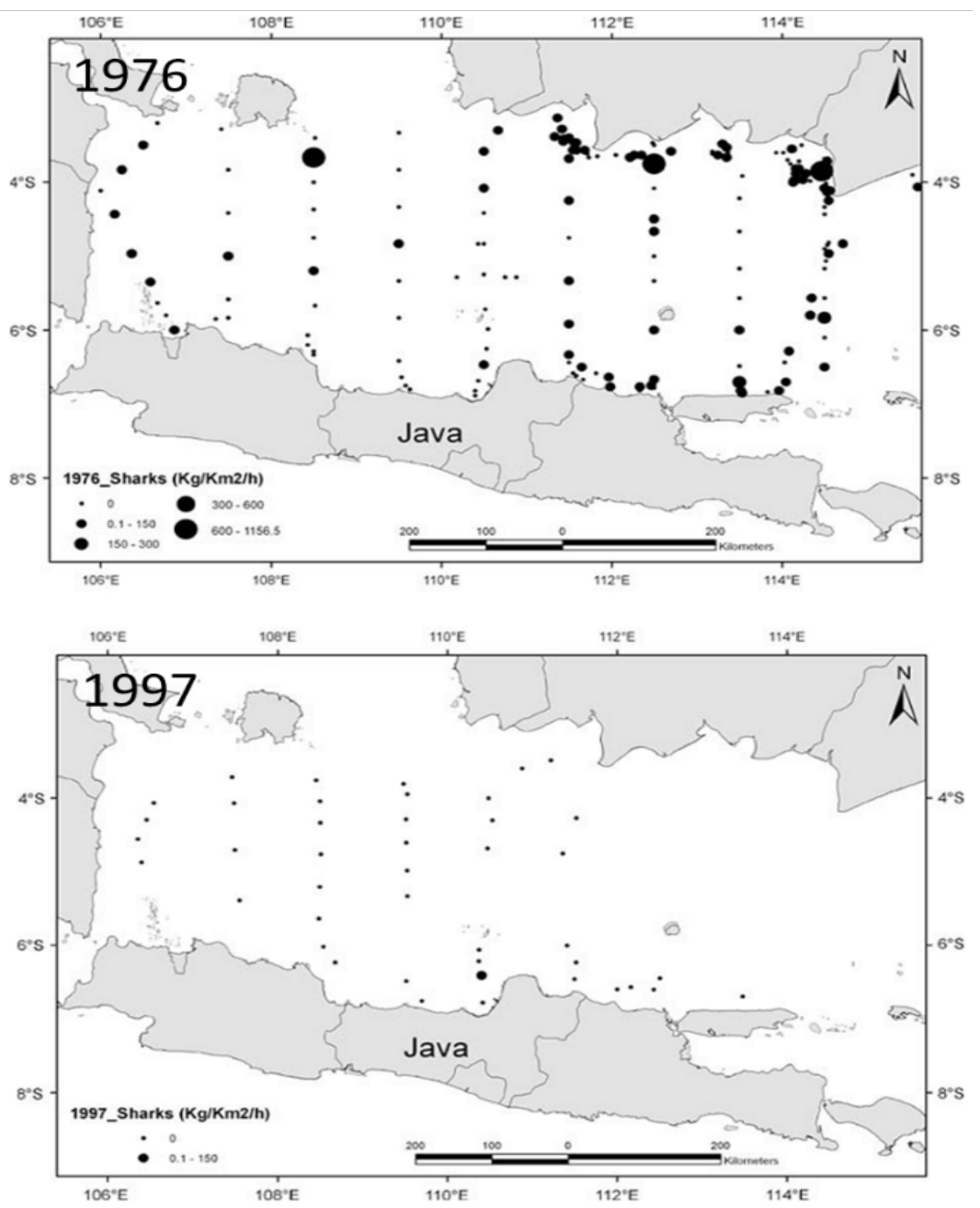

Gambar 5. Perubahan laju penangkapan ikan hiu di Laut Jawa pada tahun 1976 hingga 1997 (Blaber et al., 2009).

Penggunaan bom dan racun untuk menangkap ikan mungkin lebih sedikit dilakukan di perairan utara Pulau Jawa. Akan tetapi, eksploitasi sumberdaya perikanan terutama ikan hiu di lokasi tersebut lebih besar dibandingkan perairan Indonesia timur. Pada tahun 1976, telah terjadi penangkapan ikan hiu skala besar di Laut Jawa yang mencapai $600 \mathrm{~kg} / \mathrm{km}^{2} /$ jam. Akibatnya adalah pada tahun 1997, 
laju penangkapan ikan hiu di lokasi ini menurun drastis menjadi $<0.1 \mathrm{~kg} / \mathrm{km}^{2} /$ jam, karena stok ikan yang menyusut. Hal ini diperparah dengan kenyataan bahwa sebagian besar penangkapan ikan hiu hanya untuk mendapatkan siripnya yang memang paling bernilai ekonomis dibandingkan bagian tubuh yang lain (Gambar 5) (Blaber et al., 2009). Ikan hiu berperan penting dalam ekosistem terumbu karang sebagai predator puncak (apex predator), predator menengah (mesopredator), agen siklus nutrien, agen disturbansi habitat, dan agen pemusnah biota invasif, sehingga kehilangan ikan hiu dapat mengganggu jaring-jaring makanan dan aliran energi di ekosistem terumbu karang (Roff et al., 2016).

\section{PENCEMARAN PESISIR SEBAGAI FENOMENA LOKAL PENYEBAB PERUBAHAN EKOLOGI LAUT DI INDONESIA}

Beberapa fenomena lokal yang menyebabkan perubahan ekologi laut antara lain: eutrofikasi, sedimentasi, pencemaran, serangan biologi dari spesies asing, herbivora, serta penyakit (Wernberg et al., 2011). Di antara fenomena tersebut, pencemaran diduga merupakan faktor utama yang menyebabkan perubahan ekologi di Indonesia pada tingkat lokal. Indonesia beserta negara berkembang lainnya sedang mempercepat laju pembangunan terutama di kawasan pesisir, sehingga beban lingkungan di kawasan pesisir lebih berat dibandingkan kawasan lainnya. Pertumbuhan kawasan pesisir di Indonesia sudah dimulai sejak tahun
150 M di Teluk Lada, Banten oleh Kerajaan Salakanagara (Tjandrasasmita dalam Iswandi, 2015), dan hingga sekarang sudah terdapat 150 kota yang berada di kawasan pesisir mulai dari kota kecil hingga metropolitan (Iswandi, 2015). Pembangunan kawasan pesisir di satu sisi berdampak positif terhadap kondisi sosial dan ekonomi masyarakat, tetapi di sisi lain berdampak negatif terhadap lingkungan. Kasus pencemaran akibat pertumbuhan kawasan pesisir yang sangat cepat dapat dilihat secara nyata di Teluk Jakarta. Saat ini, 71 bahan kontaminan organik telah terdeteksi di sepanjang pesisir Jakarta, yang sebagian besar berasal dari produk-produk rumah tangga (Breckwoldt et al., 2016).

Selain dari kawasan pesisir, bahan pencemar juga bisa berasal dari dataran tinggi yang masuk melalui aliran sungai. Indonesia banyak memiliki sungai yang bermuara ke pantai, sehingga sebagian besar sisa aktivitas manusia yang berada di dataran tinggi, seperti pertanian akan menumpuk di kawasan pesisir. Input bahan pencemar dari aktivitas pertanian banyak terjadi di pulau yang padat penduduk, seperti Pulau Jawa. Input nitrogen ke sungai-sungai di Pulau Jawa pada tahun 2000 mencapai $>120 \mathrm{~kg} / \mathrm{km}^{2} /$ tahun, sedangkan input fosfor mencapai $>40 \mathrm{~kg} /$ $\mathrm{km}^{2} /$ tahun (Gambar 6) (Suwarno et al., 2014). Hal ini diperparah dengan laju input sedimen dari sungai-sungai Indonesia yang mencapai $1630 \mathrm{MT} /$ tahun, yang mempercepat laju sedimentasi di kawasan pantai (Syvitski et al., 2005). 


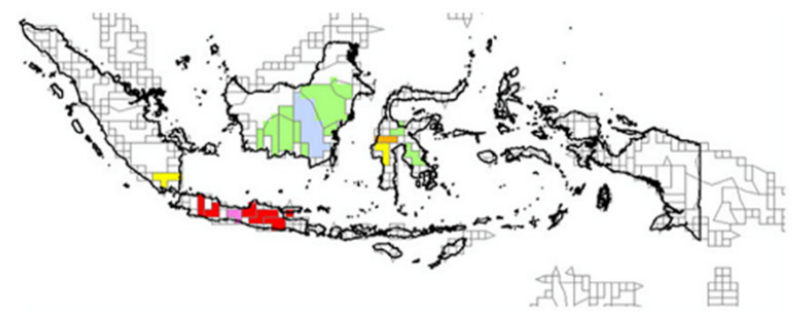

Nitrogen inputs to rivers $\left(\mathrm{kg} \mathrm{km}^{-2} \mathrm{y}^{-1}\right)$
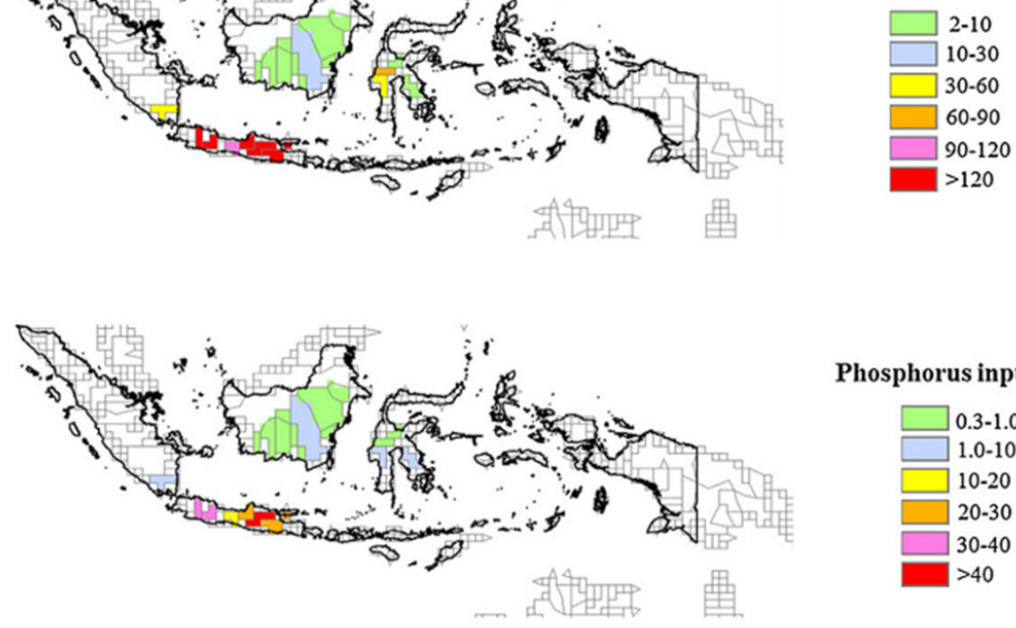

Phosphorus inputs to rivers $\left(\mathrm{kg} \mathrm{km}^{-2} \mathrm{y}^{-1}\right)$

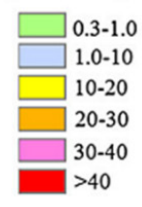

Gambar 6. Laju input nitrogen dan fosfor dari sungai-sungai di Indonesia ke kawasan pesisir (Suwarno et al., 2014).

Perpaduan antara input bahan pencemar (bahan organik, nitrogen, dan fosfor), dan sedimentasi memberikan dampak yang signifikan terhadap ekosistem pesisir, terutama komunitas bentos. Lebih dari $80 \%$ variasi komunitas bentos di Kepulauan Seribu, Jakarta, dipengaruhi laju sedimentasi, $\mathrm{NO}_{2}, \mathrm{PO}_{4}$, dan klorofil a (Baum et al., 2015). Lebih spesifik, perubahan kualitas air laut di Teluk Jakarta dari tahun 1920-1940 hingga 2005 telah menghilangkan $>50 \%$ spesies moluska (van der Meij et al., 2009), dan $>85 \%$ spesies karang Acroporidae (van der Meij et al., 2010).

\section{PENUTUP}

Hasil telaah beberapa pustaka menunjukkan bahwa penyebab utama perubahan ekologi laut di Indonesia adalah pemanasan global, eksploitasi sumberdaya perikanan, dan pencemaran pesisir. Ketiga fenomena tersebut terjadi pada skala global, regional, dan lokal, sehingga beban kerusakan ekologi laut di Indonesia terakumulasi di tingkat lokal dan bervariasi antara satu daerah dengan daerah lainnya. Oleh karena itu, penanganan perubahan ekologi laut di Indonesia, baik melalui penerapan teknologi, regulasi, dan pendidikan, harus dilakukan mulai dari tingkat global hingga lokal. Penanganan pemanasan global, dalam hal ini lebih banyak disebabkan oleh emisi gas karbondioksida, membutuhkan kerjasama internasional, sedangkan penanganan eksploitasi sumberdaya perikanan dan pencemaran pesisir dapat dilakukan pada skala nasional atau lokal. Perubahan ekologi laut di Indonesia pada skala nasional dan lokal dapat diminimalkan dengan merencanakan tata wilayah laut (Marine Spatial Planning atau MSP) dalam bentuk kawasan perlindungan laut (Marine Protected Area atau MPA). 


\section{DAFTAR PUSTAKA}

Baum, G., H.I. Januar, S.C.A. Ferse and

A. Kunzmann. 2015. Local and regional impacts of pollution on coral reefs along the Thousand Islands north of the megacity Jakarta, Indonesia. PLos ONE 10: https://doi.org/10.1371/ journal.pone.0138271

Blaber, S.J.M., C.M. Dichmont, W. White, R. Buckworth, L. Sadiyah, B. Iskandar, S. Nurhakim, R. Pillans, R. Andamari, Dharmadi and Fahmi. 2009. Elasmobranchs in southern Indonesian fisheries: The fisheries, the status of the stocks and management options. Reviews in Fish Biology and Fisheries 19: 367-391.

Breckwoldt, A., L. Dsikowitzky, G. Baum, S.C.A. Ferse, S. van der Wulp, I. Kusumanti, A. Ramadhan and L. Adrianto. 2016. A review of stressors, uses and management perspectives for the larger Jakarta Bay area, Indonesia. Marine Pollution Bulletin 110: 790-794.

Burke, L., K. Reytar, M. Spalding and A. Perry. 2011. Reefs at Risk Revisited. World Resources Institute, Washington, DC: $114 \mathrm{hlm}$.

Edinger, E.N., J. Jompa, G.V. Limmon, W. Widjatmoko and M.J. Risk. 1998. Reef degradation and coral biodiversity in Indonesia: Effects of land- based pollution, destructive fishing practices and changes over time. Marine Pollution Bulletin 36: 617-630.

García-Molinos, J., B.S. Halpern, D.S. Schoeman, C.J. Brown, W. Kiessling, P.J. Moore, J.M. Pandolfi, E.S. Poloczanska, A.J. Richardson and M.T. Burrows. 2016. Climate velocity and the future global redistribution of marine biodiversity. Nature Climate Change 6: 83-88.

Guest, J.R., A.H. Baird, J.A. Maynard, E. Muttaqin, A.J. Edwards, S.J. Campbell, K. Yewdall, Y.A. Affendi and L.M. Chou. 2012. Contrasting patterns of coral bleaching susceptibility in 2010 suggest an adaptive response to thermal stress. PLoS ONE 7: https:// doi.org/10.1371/journal. pone. 0033353

Guzman, H.M. and J. Cortés. 2007. Reef recovery 20 years after the 1982-1983 El Niño massive mortality. Marine Biology 151: 401-411.

Iswandi, R. 2015. Perencanaan dan Pengembangan Kota Pesisir Berwawasan Lingkungan. Unhalu Press, Kendari: 119 hlm.

Lewis, S.L. and M.A. Maslin. 2015. Defining the anthropocene. Nature 519: 171-180.

McCulloch, M., J. Falter, J. Trotter and P. Montagna. 2012. Coral resilience to ocean acidifi- 
cation and global warming through $\mathrm{pH}$ up-regulation. Nature Climate Change 2: 623-627.

Peñaflor, E.L., W.J. Skirving, A.E. Strong, S.F. Heron and L.T. David. 2009. Sea-surface temperature and thermal stress in the Coral Triangle over the past two decades. Coral Reefs 28: 841-850.

Rockström, J. 2009. A safe operating space for humanity. Nature 461: 472-475.

Roff, G., C. Doropoulos, A. Rogers, Y.M. Bozec, N.C. Krueck, E. Aurellado, M. Priest, C. Birrell and P.J. Mumby. 2016. The ecological role of sharks on coral reefs. Trends in Ecology \& Evolution 31: 395-407.

Steinke, S., M. Prange, C. Feist, J. Groeneveld and M. Mohtadi. 2014. Upwelling variability off southern Indonesia over the past two millennia. Geophysical Research Letters 41: 7684-7693.

Suwarno, D., A. Löhr, C. Kroeze and B. Widianarko. 2014. Fast increases in urban sewage inputs to rivers of Indonesia. Environment, Development and Sustainability 16: 10771096.

Sydeman, W.J., E. Poloczanska, T.E. Reed and S.A. Thompson. 2015. Climate change and marine vertebrates. Science 350: $772-777$.
Syvitski, J.P.M., C.J. Vörösmarty, A.J. Kettner and P. Green. 2005. Impact of humans on the flux of terrestrial sediment to the global coastal ocean. Science 308: 376-380.

van der Meij, S.E.T., R.G. Moolenbeek and B.W. Hoeksema. 2009. Decline of the Jakarta Bay Molluscan fauna linked to human impact. Marine Pollution Bulletin 59: 101107.

van der Meij, S.E.T., Suharsono and B.W. Hoeksema. 2010. Long-term changes in coral assemblages under natural and anthropogenic stress in Jakarta Bay (1920-2005). Marine Pollution Bulletin 60: 1442-1454.

Warwick, R.M., K.R. Clarke and Suharsono. 1990. A statistical analysis of coral community responses to the 1982-83 El Niño in the Thousand Islands, Indonesia. Coral Reefs 8: 171-179.

Wernberg, T., B.D. Russell, P.J. Moore, S.D. Ling, D.A. Smale, A. Campbell, M.A. Coleman, P.D. Steinberg, G.A. Kendrick and S.D. Connell. 2011. Impacts of climate change in a global hotspot for temperate marine biodiversity and ocean warming. Journal of Experimental Marine Biology and Ecology 400: 7-16. 